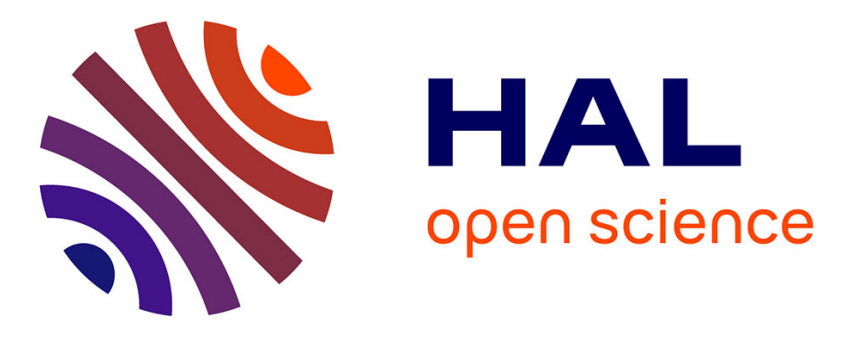

\title{
Sea surface temperature variability in the North Western Mediterranean Sea (Gulf of Lion) during the Common Era
}

\author{
Marie-Alexandrine Sicre, Bassem Jalali, Belen Martrat, Sabine Schmidt, \\ Maria-Angela Bassetti, Nejib Kallel
}

\section{To cite this version:}

Marie-Alexandrine Sicre, Bassem Jalali, Belen Martrat, Sabine Schmidt, Maria-Angela Bassetti, et al.. Sea surface temperature variability in the North Western Mediterranean Sea (Gulf of Lion) during the Common Era. Earth and Planetary Science Letters, 2016, 456, pp.124-133. 10.1016/j.epsl.2016.09.032 . hal-01386646

\section{HAL Id: hal-01386646 \\ https://hal.sorbonne-universite.fr/hal-01386646}

Submitted on 24 Oct 2016

HAL is a multi-disciplinary open access archive for the deposit and dissemination of scientific research documents, whether they are published or not. The documents may come from teaching and research institutions in France or abroad, or from public or private research centers.
L'archive ouverte pluridisciplinaire HAL, est destinée au dépôt et à la diffusion de documents scientifiques de niveau recherche, publiés ou non, émanant des établissements d'enseignement et de recherche français ou étrangers, des laboratoires publics ou privés. 


\section{Sea surface temperature variability in the North Western Mediterranean Sea (Gulf of Lion) during the Common Era}

Marie-Alexandrine Sicre ${ }^{\mathrm{a}, *}$, Bassem Jalali ${ }^{\mathrm{a}, \mathrm{b}}$, Belen Martrat ${ }^{\mathrm{c}}$, Sabine Schmidt ${ }^{\mathrm{d}}$, Maria-Angela Bassetti $^{\mathrm{e}}$, Nejib Kallel ${ }^{\mathrm{b}}$

${ }^{a}$ Sorbonne Universités (UPMC, Univ. Paris 06)-CNRS-IRD-MNHN, LOCEAN Laboratory, 4 place Jussieu, F75005 Paris, France.

* Corresponding author : Marie-Alexandrine.Sicre@locean-ipsl.upmc.fr

${ }^{\mathbf{b}}$ Université de Sfax, Faculté des Sciences de Sfax, Laboratoire GEOGLOB, BP.802, 3038, Sfax, Tunisia.

c Department of Environmental Chemistry, Spanish Council for Scientific Research (IDÆA-CSIC), 08034 Barcelona, Spain

${ }^{\mathrm{d}}$ UMR5805 EPOC, Université de Bordeaux, Avenue Geoffroy Saint-Hilaire, 33615 Pessac, France

${ }^{\text {e } C E F R E M, ~ C N R S ~ U M R 5110, ~ U n i v e r s i t e ́ ~ d e ~ P e r p i g n a n, ~ A v e n u e ~ J .-P . ~ A l d u y, ~} 66860$ Perpignan, France.

\section{ABSTRACT}

This study investigates the multidecadal-scale variability of sea surface temperatures (SSTs) in the convection region of the Gulf of Lion (NW Mediterranean Sea) over the full past 2000 yr (Common Era) using alkenone biomarkers. Our data show colder SSTs by $1.7^{\circ} \mathrm{C}$ over most of the first millennium $(200-800 \mathrm{AD})$ and by $1.3^{\circ} \mathrm{C}$ during the Little Ice Age (LIA; 1400$1850 \mathrm{AD})$ than the 20 th century mean $\left(17.9^{\circ} \mathrm{C}\right)$. Although on average warmer, those of the Medieval Climate Anomaly (MCA) (1000-1200 AD) were lower by $1^{\circ} \mathrm{C}$. We found a mean SST warming of $2{ }^{\circ} \mathrm{C} / 100 \mathrm{yr}$ over the last century in close agreement with the 0.22 and $0.26^{\circ} \mathrm{C} /$ decade values calculated for the western Mediterranean Sea from in situ and satellite data, respectively. Our results also reveal strongly fluctuating SSTs characterized by cold extremes followed by abrupt warming during the LIA. We suggest that the coldest decades of the LIA were likely caused by prevailing negative EA states and associated anticyclone blocking over the North Atlantic resulting in cold continental northeasterly winds to blow over Western Europe and the Mediterranean region.

Keywords: Mediterranean Sea; sea surface temperature; alkenones; Common Era; East Atlantic mode; atmospheric blocking 


\section{Introduction}

In the past decade, major efforts have been done to document the multi-decadal variability of the sea surface temperatures during the Common Era (last 2,000 yr) and to explore the role of external forcings (solar, volcanism, greenhouse gases) by combining paleo records and numerical simulations of the last millennium climate (McGregor et al., 2015; Sicre et al., 2011). Although the number of pre-instrumental reconstructions of sea surface temperature (SST) resolving the decadal scale has increased significantly they are still insufficient to precisely describe the space-time climate variability both at global and regional scales. This is particularly true for the Mediterranean region for which very few records exist despite alarming future climate projections (Lionello et al., 2006). Indeed, the Mediterranean region is one of the most sensitive areas to climate change owing to its geographical location between the temperate climate of Europe and the arid climate of North Africa. Because of this, even minor modifications in the extension and intensity of these climate zones can substantially alter the Mediterranean climate making this region particularly vulnerable to global warming (Lionello et al., 2006). In its history, the Mediterranean region has undergone important changes that can be investigated to better understand present-day interactions between global and regional climate and the underlying driving mechanisms.

The Mediterranean climate is strongly influenced by the large-scale mid-latitude atmospheric circulation of the North Atlantic (NA) and primarily the East Atlantic pattern (EA) and the North Atlantic Oscillation (NAO; Hurrell, 1995). The NAO, the dominant mode of atmospheric variability in the NA, reflects the atmospheric pressure difference between the Azores High and Icelandic low. The NAO state determines the latitudinal position of the NA storm tracks driving the Mediterranean winter precipitation, but its role on Mediterranean SSTs is secondary (Lionello et al., 2006). Instead, the EA has been recently recognized as the main controlling factor of the SST variability of the Mediterranean Sea, particularly in the western basin (Josey et al., 2011). The EA mode has a similar North South dipole structure as the NAO but its centers of action are displaced southeastward, which results in a stronger link 
with the subtropical climate than NAO. Teleconnections with El Nino Southern Oscillation (ENSO) have also been suggested mainly to explain winter rainfall in some areas of the Mediterranean region (Alpert et al., 2006). Finally, the influence of the Atlantic Multidecadal variability (AMV) (Knight et al., 2006) has been recently pointed out, yet the dynamical links between AMV and Mediterranean SSTs is still an open question. Indeed, oceanic processes have been suggested based on the detection of AMV-like 70-yr period oscillations in the Mediterranean SSTs (Marullo et al., 2011) while according to the study of Mariotti and Dell'Aquila (2012) atmospheric transmission of AMV is more likely.

The complex topography of the Mediterranean basin modifies the large-scale atmospheric flow and subsequently influences the climate characteristics at a local scale. In the northwestern Mediterranean Gulf of Lion (GoL), interactions between the mid-latitude westerly winds and the Alps result in northerly winds blowing offshore in the South of France, called Mistral (Jiang et al., 2003). This cold and dry wind blows at all seasons (climatologically $49 \%$ of wind frequency is in the northwest quadrant; Burlando, 2009), but more strongly in winter and spring (Jiang et al, 2003) causing intense surface water cooling. Najac et al. (2009) have shown that Mistral is favored by anticyclonic blocking over the northeastern Atlantic and a low-pressure system in the central Mediterranean Sea (Fig. 1), a synoptic configuration described by negative EA that focuses the northerly air flow over France. Despite previous suggestions of a dynamical connection between negative NAO and the occurrence of NA blocking (Shabbar et al., 2001), the most severe Mistral episodes show only a modest correlation with NAO compared to the strong correlation with negative EA (Skliris et al., 2012; Papadopoulos et al., 2012). Ultimately, while weak westerlies during negative NAO result in cold temperature in Europe, the most severe winters occur during negative EA due to the deflection of the maritime westerly flow to the North around the anticyclonic cell returning as cold and dry northerly continental winds over Europe and the Northwestern Mediterranean Sea (Fig. 1) (Häkkinen et al., 2011). Yet, interactions exist between the two modes (Moore and Renfrew, 2011). Indeed, bivariate reconstructions have 
shown that EA modulates the strength and position of NAO centers of action and that winter severity is enhanced when both modes are in negative phase. This would for instance explain that despite similar negative NAO values, winter in Europe was much cooler in 2010 (negative EA) than in 2009 (positive EA) (Moore and Renfrew, 2011).

Mistral exerts a strong control on the SSTs in the Northwestern Mediterranean Sea and is responsible for among the coldest values found in the Gulf of Lions (GoL). Mistral also triggers intense blooms in February, March and April (FMA) when it is stronger (Bosc et al., 2004; Durrieu de Madron et al., 2013). A relationship between primary production maxima, Mistral and negative EA has also been evidenced by Olita et al. (2011). Because Mistral concurrently causes surface cooling and high primary production, alkenone-derived SSTs in the GoL are expected to well capture past changes of atmospheric conditions promoting Mistral. These unique properties motivated the choice of GoL shelf sediment for generating a high-resolution SST reconstruction over the Common Era using alkenone as a temperature proxy. Based on this time series we investigate the links between mid-latitude atmospheric variability, Mistral and SSTs in the GoL with a focus on the strong amplitude SST fluctuations observed during the Little Ice Age (LIA).

\section{Material and methods}

\subsection{Analytical procedure}

A gravity core KSGC-31 (GMO2-Carnac cruise in 2002, R/V "Le Suroît") and multi-core Gol-Ho1B (GolHo cruise in 2013, R/V "Néréis") were retrieved at virtually the same location $\left(43^{\circ} 0^{\prime} 23 \mathrm{~N} ; 3^{\circ} 17^{\prime} 56 \mathrm{E}\right.$, water depth $60 \mathrm{~m}$, Fig. 1$)$ in the Rhone river mud belt deposited onto the GoL continental mid-shelf.

The two sediment cores were sampled continuously at a sampling step of $1 \mathrm{~cm}$ and freezedried overnight. Between $2-3 \mathrm{~g}$ of dried sediments were extracted with a mixture of methanol/methylene chloride $(1: 2 \mathrm{v} / \mathrm{v})$ to recover the lipid biomarkers. Alkenones were 
further isolated from the total lipid extract by silica gel chromatography using solvent mixtures of increasing polarity. Gas chromatography (GC) analyses were performed on a Varian CX 3400 gas chromatograph equipped with a fused CP-Sil-5 silica capillary column (50 $\mathrm{m} \times 0.32 \mathrm{~mm}$ i.d.) and a flame ionization detector. Helium was used as carrier gas. The oven was temperature programed from $100^{\circ} \mathrm{C}$ to $300^{\circ} \mathrm{C}$ at a rate of $20^{\circ} \mathrm{C} \min ^{-1}$. $5 \alpha$ cholestane was added prior GC analyses for quantitation. Details on the analytical procedure can be found in Ternois et al. (1996).

Alkenones are primarily biosynthesized by the ubiquitous haptophyte algae Emiliania huxleyi. This compound series comprises a suite of methyl and ethyl $\mathrm{C}_{37}$ to $\mathrm{C}_{39}$ ketones with two or three double bonds. The $\mathrm{C}_{37}$ alkenones are used to calculate the $\mathrm{C}_{37}$ unsaturation index $\mathrm{U}_{37}^{\mathrm{K}}\left(\mathrm{U}_{37}^{\mathrm{K}}\right.$ $\left.=\mathrm{C}_{37: 2} /\left(\mathrm{C}_{37: 2}+\mathrm{C}_{37: 3}\right)\right)$ now a well-established temperature proxy in paleoceanographic studies. SSTs were calculated from the downcore $\mathrm{U}_{37}^{\mathrm{K}}$ values and the most recent global calibration published by Conte et al. $(2006)\left(\mathrm{T}=-0.957+54.293\left(\mathrm{U}_{37}^{\mathrm{K}}\right)-52.894\left(\mathrm{U}_{37}^{\mathrm{K}}\right)^{2}+28.321\left(\mathrm{U}_{37}^{\mathrm{K}}\right)^{3}\right.$, standard error estimate: $1.2^{\circ} \mathrm{C}$ ). Precision based on triplicate alkenone analyses is $0.01 \mathrm{U}_{3}^{\mathrm{K}}$ unit, which in the temperature range considered here, translates into $0.3^{\circ} \mathrm{C}$.

\subsection{Chronology}

Age control for the multi-core Gol-Ho1B is based on ${ }^{210} \mathrm{~Pb}$ dating and for gravity core KSGC31 on both ${ }^{210} \mathrm{~Pb}$ and ${ }^{14} \mathrm{C}$ dating. For the gravity core, 10 radiocarbon dates were acquired on bivalve shells with the ARTEMIS accelerator mass spectrometer (AMS) operated in the Laboratoire de Mesure du Carbone 14, Saclay (France). Radiocarbon ages were corrected for local reservoir effect of $\Delta \mathrm{R}=23 \pm 71$ (Table 1) and converted into $1 \sigma$ calendar years using the CALIB7.1 software and the marine calibration curve Marine13 (Stuiver and Reimer, 1993; Reimer et al., 2013). Linear interpolation was performed between ${ }^{14} \mathrm{C}$-dated horizons to translate each sampling depth to age expressed here in Anno Domini (AD) years

(Fig. 2). Because the two upper most ${ }^{14} \mathrm{C}$ dates indicate post-bomb ages (calibrated using 
OxCal 4.2; Ramsey and Lee, 2013) additional ${ }^{210} \mathrm{~Pb}$ and ${ }^{137} \mathrm{Cs}$ measurements were performed in the first $10 \mathrm{~cm}$ of the gravity core KSGC31 (Table 2). Note that the ${ }^{14} \mathrm{C}$ date at $18.5 \mathrm{~cm}$ $(1570 \pm 78 \mathrm{yr} \mathrm{AD})$ was considered as an outlier and discarded from the age model as it appeared incompatible with the ${ }^{14} \mathrm{C}$ modern age of the above horizons $(5.5$ and $11.5 \mathrm{~cm})$ and the presence of ${ }^{210} \mathrm{~Pb}$ and ${ }^{137} \mathrm{Cs}$ in the upper $10 \mathrm{~cm}$.

Activities of ${ }^{210} \mathrm{~Pb},{ }^{226} \mathrm{Ra},{ }^{137} \mathrm{Cs}$ and ${ }^{232} \mathrm{Th}$ were determined in the gravity core KSGC-31 and multi-core Gol-Ho1B by $\gamma$ spectrometry using a low-background high-efficiency well-shaped germanium detector equipped of a Cryo-cycle (CANBERRA; Schmidt et al., 2014) (Fig. 3). The calibration of the detector was achieved using certified IAEA reference materials (RGU1; RGTh; IAEA-135). Activities are expressed in $\mathrm{mBq} \mathrm{g}^{-1}$ and errors based on $1 \sigma$ counting statistics. ${ }^{210} \mathrm{~Pb}$ excess $\left({ }^{210} \mathrm{~Pb}_{\mathrm{xs}}\right)$ was determined by subtracting the activity supported by its parent isotope ${ }^{226} \mathrm{Ra}$ from the total ${ }^{210} \mathrm{~Pb}$ activity in the sediment. Errors in ${ }^{210} \mathrm{~Pb}_{\mathrm{xs}}$ were calculated by propagation of errors in the corresponding pair $\left({ }^{226} \mathrm{~Pa}\right.$ and $\left.{ }^{210} \mathrm{~Pb}\right)$. To compensate for potential effect of compositional changes of sediments and to optimize splicing of the multicore and gravity core records, ${ }^{210} \mathrm{~Pb}_{\mathrm{xs}}$ activities were normalized using ${ }^{232} \mathrm{Th}$ concentrations measured simultaneously by $\gamma$ counting $\left({ }^{210} \mathrm{~Pb}_{\mathrm{xs}}{ }^{\mathrm{Th}}\right)$.

Depth profiles of ${ }^{232} \mathrm{Th},{ }^{210} \mathrm{~Pb}_{\mathrm{xs}}{ }^{\mathrm{Th}}$ and ${ }^{137} \mathrm{Cs}$ activities for multicore Gol-Ho1B were determined shortly after collection at sea and prior biomarker analyses. ${ }^{210} \mathrm{~Pb}_{\mathrm{xs}}{ }^{\text {Th }}$ values show a mixed layer in the upper $4 \mathrm{~cm}$, followed by an exponential decrease with increasing depth in the core (Table 2, Fig. 3B) from which sediment age is calculated. Sediment accumulation rates were derived from the ${ }^{210} \mathrm{~Pb}_{\mathrm{xs}}{ }^{\mathrm{Th}}$ profile assuming constant flux and constant sedimentation accumulation rates (referred to as the CF:CS model, Schmidt et al. 2014). To account for compaction effect, ${ }^{210} \mathrm{~Pb}_{\mathrm{xs}}{ }^{\text {Th }}$ values were plotted against cumulative mass. A mean Mass Accumulation Rate (MAR) of $0.31 \mathrm{~g} \mathrm{~cm}^{-2} \mathrm{yr}^{-1}$ was estimated. The deposition time (in years) of each sediment layer was obtained by dividing the cumulated dry mass per unit area by the MAR (Fig. 3D). The deposition year was subsequently estimated based on the sampling year of the core, in 2013 . The ${ }^{210} \mathrm{~Pb}$ chronology indicates that the multicore Gol-Ho1B ranges from 
1960 ( \pm 5.6) to 2013 AD. ${ }^{137} \mathrm{Cs}$ was detected throughout the multi-core in agreement with the well-known pulse inputs related to the nuclear weapon test fall-out in the early sixties (maximum atmospheric fallout is in 1963 in the Northern Hemisphere) (Fig. 3C, Table 2). Comparison between ${ }^{232} \mathrm{Th},{ }^{210} \mathrm{~Pb}_{\mathrm{xs}}{ }^{\mathrm{Th}}$ and ${ }^{137} \mathrm{Cs}$ activities in KSGC31 and Gol-Ho1B cores was used to determine the material loss during gravity coring and to splice records. A shift in depth of $15 \mathrm{~cm}$ gave the best correspondence between the two profiles (Fig. 3) leading to a core-top age of $1971( \pm 1.4)$ AD for the gravity core KSGC31.

For the multicore Gol-Ho1B sediment, the sedimentation rate decreases from $0.47 \mathrm{~cm} \mathrm{yr}^{-1}$ at the water-sediment interface to $0.32 \mathrm{~cm} \mathrm{yr}^{-1}$ at the base of the core. In the gravity core KSGC31, sedimentation rate determined for the upper $10 \mathrm{~cm}$ is estimated to be around 0.16

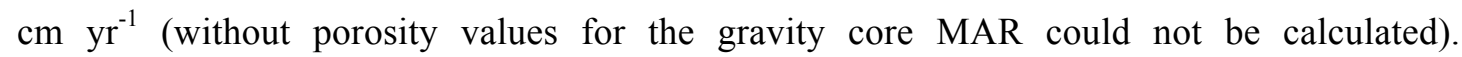
Sedimentation rate for the underlying layers derived from ${ }^{14} \mathrm{C}$ dating is on the order of $0.1 \mathrm{~cm}$ $\mathrm{yr}^{-1}$. Lower sedimentation rates in the gravity core compared to the multicore is not unusual and explained by increasing natural compaction of sediment with depth and possibly also by compaction due to the gravity coring (Sicre et al., 2011).

\section{Results}

\subsection{Industrial Era period}

Fig. 4A shows the SST reconstruction since 1850 AD obtained for the upper gravity core KSGC31 (dark green solid line) and entire multicore Gol-Ho1B (light green dashed line) records against age, based on the ${ }^{210} \mathrm{~Pb}$ and ${ }^{14} \mathrm{C}$ chronology. Values range from 16.5 to $18^{\circ} \mathrm{C}$ in the gravity core, and from 16.5 to $19^{\circ} \mathrm{C}$ in the multicore. Both records indicate comparable SST values in the overlapping interval except for the warmest value in the mid-1960s ( $19^{\circ} \mathrm{C}$ ) seen in multi-core sediment but not in the gravity core sediment. We interpreted this result by a probable artifact in the uppermost $\mathrm{cms}$ of the gravity core due to coring as suggested by smoothing in the exponential decay in the ${ }^{210} \mathrm{~Pb}$ curve (Fig. 3B). Indeed, gravity 
coring generally causes material loss and the disturbance of the uppermost sediment layers while a multi-corer typically recovers intact surface sediment. The two-fold difference in sedimentation rates $\left(0.32\right.$ versus $\left.0.16 \mathrm{~cm} \mathrm{yr}^{-1}\right)$ between the two records in this interval translates into a difference of temporal resolution that could also account for this discrepancy. In any case, all values were considered to construct the spliced record (Fig. 4B, Fig. 5A). The full $2 \mathrm{k}$ SST reconstruction was thus obtained by combining the gravity core KSGC31 SST values from 0 to $1971 \mathrm{AD}$ and the complete multicore Gol-Ho1B SST data spanning from 1960 to 2013 AD. As can be seen in Figure 4B, the SST signal depicts an overall warming ranging from $\sim 16.5^{\circ} \mathrm{C}$ to $\sim 19^{\circ} \mathrm{C}$ during the $20^{\text {th }}$ century followed by cooling over the most recent decades. Multi-decadal scale fluctuations are superimposed to this trend. These values are among the lowest of the Mediterranean surface waters in agreement with the temperature field of the Mediterranean Sea shown in Figure 1 and previous alkenone SST data obtained from surface sediments distributed across the NW Mediterranean Sea pointing to colder SSTs in the GoL (Ternois et al., 1996).

\subsection{The Common Era (last 2k)}

Figure 6A plots the full past 2k SST record of the GoL. A 25-yr binning was applied (black line) in order to easily evaluate departures from the average value $\left(16.7^{\circ} \mathrm{C} \pm 0.7^{\circ} \mathrm{C}\right)$. The first millennium $\mathrm{AD}$ reveals several cold excursions of $\sim 1.5^{\circ} \mathrm{C}$ and a mean value cooler by $1.7^{\circ} \mathrm{C}$ than the 20th century mean $\left(17.9^{\circ} \mathrm{C}\right)$. During the MCA (ca. $1000-1200$ AD) SSTs were warmer $\left(\sim 16.9^{\circ} \mathrm{C}\right)$ but $\sim 1{ }^{\circ} \mathrm{C}$ lower than the 20 th century. Around $1200 \mathrm{AD}$, they progressively decline and display marked multi-decadal fluctuations with well-expressed minima (ca. $\sim 16^{\circ} \mathrm{C}$ ) around $1300 \mathrm{AD}, 1500 \mathrm{AD}$, mid-16s $\mathrm{AD}$ and mid-17s $\mathrm{AD}$, each followed by warm spells, the most outstanding by duration and amplitude $\left(\sim 2^{\circ} \mathrm{C}\right.$ in few decades) centered at $\sim 1700 \mathrm{AD}$. As a result, average SSTs for the LIA (1400 - 1850 AD) were $1.3^{\circ} \mathrm{C}$ colder than the 20th century and not as cold as the first millennium during which post-cooling temperature rebounds above average are absent. In the following section, we 
compare the proxy and instrumental data and analyze the full $2 \mathrm{k}$ SST reconstruction with a focus on the high amplitude SST oscillations of the LIA.

\section{Discussion}

\subsection{The Industrial Era SST signal}

Figures 5 shows the Gol-Ho1B_KSGC-31 spliced SST reconstruction, the instrumental annual mean and late winter-early spring (FMA) temperature time series average over a $5^{\circ} \mathrm{x}$ $\begin{array}{llllll}5^{\circ} & \text { grid } & \text { from } & \text { Kaplan } & \text { SST } & \text { V2 }\end{array}$ (http://www.esrl.noaa.gov/psd/data/gridded/data.kaplan sst.html) since the late $19^{\text {th }}$ century. Both proxy and instrumental data show a long-term warming trend over the 20th century. The alkenone SSTs rise since $1900 \mathrm{AD}$ is $\sim 1.7^{\circ} \mathrm{C}$ but reaches $\sim 2.2^{\circ} \mathrm{C}$ when considering the 20th century only, i.e. after removing the last cold decade (2000-2012). These estimates are close to the value of $0.026{ }^{\circ} \mathrm{C} \mathrm{yr}^{-1}$ obtained from satellite SSTs for the W Mediterranean Sea over the $1985-2008$ period, and $0.022^{\circ} \mathrm{C} \mathrm{yr}^{-1}$ of the NOCS in situ SSTs from 1973 to 2008 (Skliris et al., 2012). Alkenone SSTs indicate values closer to the annual mean than FMA (Fig. 5) suggesting that alkenone production does not only take place during the months of intense Mistral (Bosc et al., 2004; Durrieu de Madron et al., 2013) but also during the warm season (late spring to summer). Vertical mixing induced by Mistral would thus sustain primary production over a longer season by replenishing surface waters with nutrients.

The SSTs decline since the beginning of the 21th century can be related to several severe winters such as the coldest on record in Europe and United Kingdom, in 2010/2011 that Moore and Renfrew (2011) attributed to combined negative NAO and EA states. These authors showed that $\mathrm{EA}^{-} \mathrm{NAO}^{-}$accounted for $50 \%$ of the winter temperature that year against $20 \%$ by NAO alone, outlining the value of considering both modes to better describe climate conditions. Winter 2012 was another exceptionally cold winter associated with a strong anticyclonic blocking in the NA (Durrieu de Madron et al., 2013) that could account together with winter 2010/2011 for the cold uppermost SST value. During the $20^{\text {th }}$ century, cold SSTs in the 70 s to early 80 s are also noteworthy both in the proxy and instrumental data (Fig. 5A, 
5B, 5C). They coincide with a period of strongly negative EA (Fig. 5D) and episodes of major dense water formation in the GoL (Béthoux et al., 2002) in accordance with the role of EA on SSTs in the GoL. Regression between EA index and SSTs on $5 \mathrm{yr}$ binned values since 1950 were calculated to account for age model uncertainties. The obtained Pearson correlation coefficient, $r=0.45$ (at the $95 \%$ confidence interval) is close to values calculated using instrumental data $(0.58$ for NOCS in situ SSTs and 0.50 for satellite SSTs in the W Mediterranean, at the 95\% confidence interval) (Skliris et al., 2012).

\subsection{General SST trends over the past $2000 \mathrm{yr}$}

In this section, we compare the SST signal of the GoL with other Mediterranean and North Atlantic records that may have features in common (Fig. 6). Records that document centennial scale SST variability in the Mediterranean during the Common Era are very scarce. They belong to different sectors of the W-Mediterranean basin, i.e. the Alboran Sea (Fig. 6B $\sim 30$ yr time resolution; Nieto-Moreno et al., 2013) and Balearic basin (Fig. 6C; $~ 30$ yr time resolution; Moreno et al., 2012) and cover all or part of the CE. None of them have a chronostratigraphic control during the instrumental period to evaluate the relationship between SSTs and climate processes. The high-resolution SST reconstruction from North Iceland (MD99-2275; Sicre et al., 2008) was also considered for a regional analysis of the data because its cross-analysis with instrumental data has shown a strong control of NAO on SSTs (Sicre et al., 2011). Precision on the age model of this core based on tephrochronology is on the order of the decade while for the other cores it is on the order of several decades (Table 1).

All records shown in Fig. 6 are based on alkenone SSTs, but primary production patterns have different characteristics depending on the location of each core in the Mediterranean Sea. While the GoL belongs to a blooming regime tightly linked to Mistral, the Alboran and Balearic Sea relate to different primary production patterns as defined by D'Ortenzio and Ribera d'Alcala (2009). In the Balearic Sea, chlorophyll concentrations show algal blooms of moderate amplitude and variable timing that occur in spring sporadically. This area thus 
combines periods of enhanced production with oligotrophic conditions leading to an erratic regime classified as an intermittently blooming region (D'Ortenzio and Ribera d'Alcala, 2009). In the Alboran Sea, the seasonal cycle of phytoplankton production is the most chaotic of the Mediterranean (D’Ortenzio and Ribera d'Alcala, 2009). Primary production exhibits a strong inter-annual variability with a pronounced production peak in February - March and in fall (October). It is also strongly influenced by Atlantic inflow waters and meso-scale gyre induced upwelling which all together leads to confounding response of phytoplankton to physical forcings (Bosc et al., 2004; D’Ortenzio and Ribera d'Alcala, 2009). These cores thus belong to biogeographical clusters with temporal and dynamical regimes that are distinct from the GoL, including in its unique link to atmospheric forcing (see Fig. 4 in D'Ortenzio and Ribera d'Alcala, 2009). Considering age model uncertainties, lower temporal resolution and the lack of instrumental control to evaluate the ability of local alkenone SSTs to capture climatic information, only broad features of the records were examined for this comparison.

As can be seen in Fig. 6, the long-term cooling ending at $\sim 1800$ AD is shared by all almost sites and consistent with the recent finding of McGregor et al. (2015) of a global ocean cooling from 0 to $1800 \mathrm{AD}$ that, according to model simulations of the pre-industrial millennium climate (801 - 1800 AD) would be imputable to volcanism. This trend reversed in the GoL and Alboran Sea around $1800 \mathrm{AD}$, but persisted off N. Iceland because of sustained sea ice occurrence, even in lower abundance during 20th century than the LIA (MarciasFauria et al., 2010). Unexpectedly, the absence of warming is also notable in the Balearic record as modern SSTs show rising values both in the Eastern and Western Mediterranean (Skliris et al. 2012; Papadopoulos et al., 2012) and in European land-based T reconstructions (Luterbacher et al., 2004). The lack of age control of the past ca. $500 \mathrm{yr}$ (Fig. 6C, dashed lines) and extrapolation of the age model in the upper core is the probable explanation for this discrepancy. Another salient feature of these SST records, in common with the GoL, is the distinctly cooler first millennium as compared to the MCA off N. Iceland while in the Balearic basin it is almost muted. In contrast, the last millennium cooling at the onset of the 
LIA is observed in all records, though not synchronously. It is much abrupt off $\mathrm{N}$. Iceland due to the imprint of sea ice on SSTs associated with the southward shift of the polar front under weakened NAO (Trouet et al., 2009).

As earlier outlined, the most outstanding feature of the GoL SST signal is the high amplitude oscillations and in particular the rebounds above the mean observed during the LIA that are not seen during the first millennium. Interestingly, while sea ice was common in the North Atlantic (Massé et al., 2008) and the northward oceanic heat transport reduced (Lund et al., 2006) during the LIA, the first millennium is a period of minimum sea ice cover and enhanced northward advection of heat. In the next section we investigate causes for the outstanding SST fluctuations of the LIA in the GoL and explore past changes in atmospheric modes of variability and notably EA.

\subsection{SSTs and large-scale climate variability modes over the last millennium}

Multidecadal to centennial scale variability of the GoL SSTs over the past $1000 \mathrm{yr}$ (Fig. 7E) is explored in light of high-resolution proxy data from the adjacent North Atlantic, i.e. Iceland (Sicre et al., 2011; Larsen et al., 2013; Ólafsdóttir et al., 2013; Fig. 7B, 7C), the Iceland Basin (Moffa-Sanchez et al., 2014, Fig. 7D), the Swiss Alp glaciers (Holzhauser et al., 2005, Fig. 7A), and western Europe land temperatures (Luterbacher et al., 2004, Fig. 7F), as well as the NAO index (Ortega et al., 2015; Fig. 7G) and solar activity reconstructed by Steinhilber et al. (2012) (Fig. 7H) to investigate the role of large-scale atmospheric low frequency variability and oceanic processes.

Previous proxy reconstructions have shown that during the MCA surface waters were generally warmer along the path of the North Atlantic Current (Keigwin, 1996; Sicre et al., 2008; Richter et al. 2009) due to stronger Atlantic Meridional Overturning Circulation (AMOC) consistent with the hypothesis that positive NAO phase (Fig. $7 \mathrm{H})$ prevailed during this period and that strong NAO enhances AMOC (Delworth and Greatbach, 2000). Relatively warm and/or wet summers resulted in increase melting and glacier retreat in Iceland (Larsen et al., 2013; Ólafsdóttir et al., 2013) (Fig. 7B) and in the Alps (Holzhauser et 
al., 2005; Denton and Broecker, 2008) (Fig. 7A). Off North Iceland, the stepwise SST increase $\sim 1000 \mathrm{AD}$ indicates a northward migration of the polar front within a few decades (Fig. 7C) a feature that is not seen in the $\mathrm{Mg} / \mathrm{Ca}$ of $\mathrm{G}$. inflata South of Iceland (RAPiD17-15, 6yr time resolution; Fig. 7D) where surface water properties are mainly shaped by the strength of the subpolar gyre (Moffa-Sanchez et al., 2014). In the GoL, SSTs also generally warm (Fig. 7E). The transition to colder conditions between 1200 and $1300 \mathrm{AD}$, depending on the records, is thought to be related to a weakening of NAO leading to colder climate in the North Atlantic and the adjacent Euro-Mediterranean region (Trouet et al., 2009).

All independent proxy records shown in Fig. 7 point to more severe conditions during the LIA and the return of seasonal sea ice but with differences in the decadal structure of the signals. SSTs in the GoL and S. Iceland basin (Fig. 7D, 7E) indicates that cooling occurred in parallel during the early LIA (1400 to $1550 \mathrm{AD}$ ), but tend to vary in opposite phase during the Late LIA. Notably, between 1530 and $1680 \mathrm{AD}$, cold SSTs in the GoL contrast with warm surface waters South of Iceland confirming previous findings of Richter et al. (2009) at Feni drift of unexpected mild conditions in the subpolar North Atlantic. According to Larsen et al. (2013) this warmth would have been responsible for the retreat of the Langjökull ice cap from 1550 to $1680 \mathrm{AD}$ (Fig. 7B). Advection of temperature anomalies from the tropical Atlantic combined with reduced heat loss to the atmosphere under weakened NAO have been proposed as possible explanations for these unexpected warm conditions during the LIA under reduced AMOC (Richter et al., 2009). Concomitantly, coldest winters in Europe supported by the multiproxy reconstruction of Luterbacher et al. (2004) ((Fig. 7F) and the expansion of Swiss glacier (Fig. 7A; Holzhauser et al., 2005; Denton and Broecker, 2008) evidence a W-E temperature asymmetry between the cold Euro-Mediterranean climate and warm subpolar waters during this time interval. This spatial pattern contrasting warm subpolar surface waters upstream the NA anticyclonic cell with cold temperatures in downstream regions (Europe and Mediterranean Sea) is expected from blocked regimes during negative EA (Häkkinen et al., 2011). Co-eval enhanced sea ice and lower SSTs in the 
Nordic Seas (off N. Iceland) is also coherent with EA driven spatial SST pattern today (Cassou et al., 2011). Severe conditions during the LIA in the Euro-Mediterranean region can thus be seen as resulting from enhanced frequency of blocking regimes associated with negative EA on longer time scale (Cassou et al., 2011). This hypothesis is supported by modeling experiments performed for the second half of the $20^{\text {th }}$ century and the Late Maunder Minimum (1645 - $1715 \mathrm{AD})$ showing that NA blocking is favored by lower solar activity that prevailed during the LIA (Nesmé-Ribes et al., 1993; Barriopedro et al., 2008). Rebounds above average would in turn reflect rapid shifts of the EA state towards more positive values implying stronger links with the subtropical climate and weaker Mistral. Overall, this set of proxy records exhibits a spatial temperature pattern that is coherent in sign with persistent anticyclone blocking and negative EA promoted by low solar activity of the LIA (Fig. 7H), in particular towards the Late LIA. Our interpretation of the GoL data together with highresolution records distributed across the NA/Euro-Mediterranean region thus supports the hypothesis that EA played an important role in the (late) LIA climate early formulated based on one single record in the NA (RAPiD17-15) by Moffa-Sanchez et al. (2014).

\section{Conclusions}

A unique SST reconstruction resolving decadal variability was developed over the full Common Era from shelf sediments in the convection region of the GoL (NW Mediterranean Sea). The tight link between alkenone-derived SSTs, Mistral and EA, the dominant mode of variability in the Mediterranean Sea, was used to investigate the climate of the Common Era in the NW-Mediterranean Sea and notably the strong fluctuations of the LIA. Comparison between instrumental and proxy data over the 20th century revealed a similar warming trend of about $2^{\circ} \mathrm{C}$. SSTs during the MCA $(1000-1200 \mathrm{AD})$ were among the warmest of the preindustrial last millennium though $\sim 1^{\circ} \mathrm{C}$ lower than those of the $20^{\text {th }}$ century. Most of the first millennium (200 -800 AD) and the LIA both indicate cold climate conditions but the LIA differ by the presence of remarkable cold extremes followed by above average temperature rebounds. Cold decades were found to reflect strong heat loss caused by negative EA and 
associated NA blocking regimes creating the conditions for intensified and cold Mistral flow. Regional synthesis of high-resolution land and marine time series from the NA and EuroMediterranean region further highlighted a W-E temperature asymmetry during the late LIA that is spatially coherent with persistent blocked regimes under negative EA and weak NAO. Reinforced northerly flow (Mistral) over Western Europe would have been favored by low solar activity.

ACKNOWLEDGMENTS: We thank CNRS and the MISTRALS/PALEOMEX program for financial support and the Ocean2k working group of the Past Global Changes (PAGES) project for discussions. We are very grateful to Nabil Sultan, Ifremer for providing facilities at sea and the crew operating the GMO2 Carnac cruise. We are also thankful for the crew of the N/V Néréis of the "Observatoire Océanographique de Banuyls" (OOB). We also thank the Laboratoire de Mesure du Carbone 14, UMS 2572, ARTEMIS for 14C measurements by mass accelerator spectrometry in the frame of the National Service to CNRS, CEA, IRD, IRSN and Ministère de la Culture et de la Communication. B.M. wishes to express her thanks to the CSIC-Ramón y Cajal post-doctoral program RYC-2013-14073 and the Shackleton Fellowship (Clare Hall College). This dataset is available on the NOAA database (http://www.esrl.noaa.gov/). 
Alpert, P., Baldi, M., Ilani, R., Krichak, S., Price, C., Rodo, X., Saaroni, H., Ziv, B., Pavel Kishcha, P., Barkan, J., Mariotti, A., and Xoplaki, E., 2006. Relations between climate variability in the Mediterranean region and the tropics: ENSO, South Asian and African monsoons, hurricanes and Saharan dust. Developments in Earth and Environmental Sciences, 4, 149-177.

Barriopedro, D., García-Herrera, R., Huth, R., 2008. Solar modulation of Northern Hemisphere winter blocking. J. Geophys. Res. Atmos, 113, D14118.

Béthoux, J.P., Durieu de Madron, X., Nyffeler, F., Tailliez, D., 2002, Deep water in the western Mediterranean: peculiar 1999 and 2000 characteristics, shelf formation hypothesis, variability since 1970 and geochemical inferences. J. Mar. Sys., 33-34, 117-131.

Bosc, E., Bricaud, A., Antoine, D., 2004. Seasonal and interannual variability in algal biomass and primary production in the Mediterranean Sea, as derived from 4 years of SeaWiFS observations. Glob. Biogeochem. Cycles, 18, 1-17.

Burlando, M., 2009. The synoptic-scale surface wind climate regimes of the Mediterranean Sea according to the cluster analysis of ERA-40 wind fields, Theor Appl. Climatol., 96, 69-83.

Cassou, C., Minvielle, M., Terray, L., Perigaud, C., 2011. A statistical-dynamical scheme for reconstructing ocean forcing in the Atlantic. Part I: weather regimes as predictors for ocean surface variables. Climate Dynamics, 36, 19-39.

Conte, M.H., Sicre, M.-A., Rühlemann, C., Weber, J.C., Schulte, S., Schulz-Bull, D., Blanz, T., 2006. Global temperature calibration of the alkenone unsaturation index (UK37) in surface waters and comparison with surface sediments. Geochem. Geophys. Geosyst., 7, Q02005.

Delworth T.L., Greatbach, R., 2000. Multidecadal thermohaline circulation variability driven by atmospheric surface flux forcing. J. of Clim., 13, 1481-1495.

Denton, G.H., Broecker, W.S., 2008. Wobbly ocean conveyor circulation during the Holocene? Quat. Sci. Rev. 27, 1939-1950

Durrieu de Madron, X., Houpert, L., Puig, P., Sanchez-Vidal, A., Testor, P., Bosse, A., Estournel, C., Somot, S., Bourrin, F., Bouin, M. N., Beauverger, M., Beguery, L., Calafat, A., Canals, M., Cassou, C., Coppola, L., Dausse, D., D’Ortenzio, F., Font, J., Heussner, S., Kunesch, S., Lefevre, D., Le Goff, H., Martín, J., Mortier, L., Palanques, A., Raimbault, P., 2013. Interaction of dense shelf water 
cascading and open-sea convection in the northwestern Mediterranean during winter 2012. Geophys. Res. Lett. 40, 1379-1385.

D’Ortenzio, F., Ribera d'Alcala M., 2009. On the trophic regimes of the Mediterranean Sea: a satellite analysis. Biogeosciences, 6, 1-10.

Häkkinen, S., Rhines, P.B., Worthen, D.L., 2011. Atmospheric blocking and Atlantic multidecadal ocean variability. Science, v. 334, no. 6056, p. 655-659.

Holzhauser, H., Magny, M., Zumbühl, H.J., 2005. Glacier and lake-level variation in west-central Europe over the last 3500 years. The Holocene 15, 789-801.

Hurrell, J.W, 1995. Decadal trends in the North Atlantic Oscillation: regional temperatures and precipitation. Science 269, 676-679.

Jiang, Q., Smith, R.B., Doyle, J. 2003. The nature of the mistral: Observations and modelling of two MAP events. Q.J.R. Meteorol. Soc. 129, 857-875. doi:10.1256/qj.02.21

Josey, S.A., Somot, S., Tsimplis, M., 2011, Impacts of atmospheric modes of variability on Mediterranean Sea surface heat exchange. Journal of Geophysical Research: Oceans, v. 116, p. C02032.

Kaplan, A., Cane, M., Kushnir, Y. Clement, A., Blumenthal, M., Rajagopalan, B., 1998. Analyses of global sea surface temperature 1856-1991. Journal of Geophysical Research, 103, 18,567-18,589

Keigwin, L.D., 1996. The little ice age and medieval warm period in the Sargasso Sea. Science, 274, 1504-1508.

Knight, J.R., Folland, C.K., Scaife, A.A., 2006. Climate impacts of the Altantic Multidecadal Oscillation. Geophys. Res. Lett., 33, L17706, doi:1029/2006GL026242.

Larsen, D.J., Miller, G.H., Geirsdóttir, Á., 2013. Asynchronous Little Ice Age glacier fluctuations in Iceland and European Alps linked to shifts in subpolar North Atlantic circulation. Earth and Planet. Sci. Lett. 380, 52-59.

Lionello, P., Malanotte-Rizzoli, P., Boscolo, R., Alpert, P., Artale, V., Li, L., Luterbacher, J., May, W., Trigo, R., Tsimplis, M., Ulbrich, U., Xoplaki, E., 2006. The Mediterranean climate: An overview of the main characteristics and issues, in Lionello P. and Boscolo, R., eds. Developments in Earth and Environmental Sciences, Volume 4, Elsevier, p. 1-26.

Lund, D.C., Lynch-Steiglitz, J., Curry, W.B., 2006. Gulf Stream density structure and transport during the past millennium. Nature, 444, doi:10.1038/nature05277. 
Luterbacher, J., Dietrich, D., Xoplaki, E., Grosjean, M., Wanner, H., 2004. European seasonal and annual temperature, trends and extremes since 1500. Science, 303, 1499-1503.

Massé, G., Rowland, S.J., Sicre, M.-A., Jacob, J., Jansen, E., Belt, S.T., 2008. Abrupt climate changes for Iceland during the last millennium: Evidence from high-resolution sea ice reconstructions. Earth and Planet. Sci. Lett. 269, 565-569.

Marcias-Fauria, M., Grinsted, A. Helama, S. Moore, J. Timonen, M. Martma, T. Isaksson, E. Eronen, M., 2010. Unprecedented low twentieth century winter sea ice extent in the Mestern Nordic Seas since A.D. 1200. Clim. Dyn. 34, 781-795.

Mariotti, A., Dell'Aquila, A., 2012. Decadal variability in the Mediterranean region: role of large scale forcing and regional processes. Clim. Dyn. 38, 1129-1145.

Marullo, S., Artale, V., Santoleri, R., 2011. The SST multidecadal variability in the AtlanticMediterranean region and its relation to AMO. J. of Clim., 4385- 4401.

Moffa-Sanchez, P., Born, A., Hall, I.R., Thornalley, D.J.R., Barker, S., 2014. Solar forcing of North Atlantic surface temperature and salinity over the past millennium. Nature Geosci, 7, 275-278.

McGregor, H.V., Evans, M.N., Goosse, H., Leduc, G., Martrat, B., Addison, J.A., Mortyn, P.G., Oppo, D.W., Seidenkrantz, M.-S., Sicre, M.-A., Phipps, S.J., Selvaraj, K., Thirumalai, K. , Filipsson, H., Ersek, V., 2015. Robust global ocean cooling trend for the pre-industrial Common Era. Nat. Geosci. doi:10.1038/NGEO2510.

Moore, G.W.K., Renfrew, I.A., 2011. Cold European winters: interplay between the NAO and the East Atlantic mode. Atmos. Sci. Lett. 13, 1-8.

Moreno, A., Pérez, A., Frigola, J., Nieto-Moreno, V., Rodrigo-Gámiz, M., Martrat, B., GonzálezSampériz, P., Morellón, M., Martín-Puertas, C., Corella, J.P., Belmonte, Á., Sancho, C., Cacho, I., Herrera, G., Canals, M., Grimalt, J.O., Jiménez-Espejo, F., Martínez-Ruiz, F., Vegas-Vilarrúbia, T., Valero-Garcés, B.L., 2012. The Medieval Climate Anomaly in the Iberian Peninsula reconstructed from marine and lake records. Quat. Sci. Rev., 43, 16-32.

Najac, J., Boè, J., Terray L., 2009. A multi-model ensemble approach for assessment of climate change impact on surface winds in France. Clim. Dyn. 32, 615-634.

Nesmé-Ribes, E., Ferreira E.N., Sadourny R., Le Treut H. Li, Z.L., 1993. Solar dynamics and its impact on solar irradiance and the terrestrial climate. J. Geophys. Res. 98, 18923-18935. 
Nieto-Moreno, V., Martínez-Ruiz, F., Willmott, V., García-Orellana, J., Masqué, P., Sinninghe Damsté, J.S., 2013. Climate conditions in the westernmost Mediterranean over the last two millennia: An integrated biomarker approach. Org. Geochem. 55, 1-10.

Ólafsdóttir, K.B., Geirsdóttir, Á., Miller, G.H., Larsen, D.J., 2013. Evolution of NAO and AMO strength and cyclicity derived from a 3-ka varve-thickness record from Iceland. Quat. Sci. Rev. 69, $142-154$.

Olita, A., Sorgente, R., Ribotti, A., Fazioli, L., Perilli A., 2011. Pelagic primary production in the Algero-provençal basin by means of multisensory satellite data: focus on interannual variability and its drivers. Ocean Dyn., 61, 1005-1016.

Ortega, P., Lehner, F., Swingedouw, D., Masson-Delmotte, V., Raible, C.C., Casado, M., Yiou, P., 2015. A model-tested North Atlantic Oscillation reconstruction for the past millennium. Nature 523, doi:10.1038/nature14518.

Papadopoulos, V.-P., Josey, S.-A., Bartzokas, A., Somot, S., Ruiz, S., Drakopoulou, P., 2012. LargeScale Atmospheric Circulation Favoring Deep- and Intermediate-Water Formation in the Mediterranean Sea. J. Clim. 25, 6079-6091.

Ramsey, C. B., Lee, S., 2013. Recent and planned developments of the program Oxcal. Radiocarbon $55,720-730$.

Reimer, P. J., Bard, E., Bayliss, A., Beck, J. W., Blackwell, P. G., Bronk Ramsey, C., Buck, C. E., Cheng, H., Edwards, R. L., Friedrich, M., Grootes, P. M., Guilderson, T. P., Haflidason, H., Hajdas, I., Hatté, C., Heaton, T. J., Hoffmann, D. L., Hogg, A. G., Hughen, K. A., Kaiser, K. F., Kromer, B., Manning, S. W., Niu, M., Reimer, R. W., Richards, D. A., Scott, E. M., Southon, J. R., Staff, R. A., Turney, C. S. M., van der Plicht, J., 2013. IntCal13 and Marine13 Radiocarbon Age Calibration Curves 0-50,000 Years cal BP. Radiocarbon, , 55, 1869-1887, doi: 10.2458/azu_js_rc.55.16947.

Richter, T.O., Peeters, F.J.C., van Weering, T.C.E., 2009. Late Holocene (0-2.4 ka BP) surface water temperature and salinity variability, Feni Drift, NE Atlantic Ocean. Quat. Sci. Rev. 28, 1941-1955.

Schabbar, A., Huang, J., Higuchi, K., 2001. The relationship between the wintertime north Atlantic Oscillation and blocking episodes in the North Atlantic. Int. J. of Climatology, 21, 355-369.

Schmidt, S., Howa, H., Diallo, A., Martín, J., Cremer, M., Duros, P., Fontanier, C., Deflandre, B., Metzger, E., Mulder, Th., 2014. Recent sediment transport and deposition in the Cap-Ferret Canyon, South-East margin of Bay of Biscay. Deep-Sea Res. II 104, 134-144. 
Sicre, M.-A., Hall, I.R., Mignot, J., Khodri, M., Ezat, U., Truong, M.X., Eiríksson, J., Knudsen, K.-L., 2011. Sea surface temperature variability in the subpolar Atlantic over the last two millennia. Paleoceanography, 26, PA4218.

Sicre, M-A., Yiou, P., Eiriksson, J., Ezat, U., Guimbaut, E., Dahhaoui, I., Knudsen, K.-L., Jansen, E., Turon, J.-L., 2008. A 4500-year reconstruction of sea surface temperature variability at decadal time scales off North Iceland. Quat. Sci. Rev. 27, 2041-2047.

Skliris, N., Sofianos, S., Gkanasos, A., Mantziafou, A., Vervatis, V., Axaopoulos, P., Lascaratos, A., 2012. Decadal scale variability of sea surface temperature in the Mediterranean Sea in relation to atmospheric variability. Ocean Dyn. 62, 13-30.

Steinhilber, F., Abreu, J.A., Beer, J., Brunner, I., Christl, M., Fischer, H., Heikkilä, U., Kubik, P.W., Mann, M., McCracken, K.G., Miller, H., Oerter, H., Wilhelms, F., 2012. 9,400 years of cosmic radiation and solar activity from ice cores and tree rings. Proceedings of the National Academy of Sciences 109, 5967-5971, doi:10.1073/pnas.1118965109.

Stuiver, M., Reimer, P.J., 1993. Extended 14C database and revised CALIB 3.0 14C age calibration program. Radiocarbon, 35, 215-230.

Ternois, Y., Sicre, M.-A., Boireau, A., Marty, J.-C., Miquel, J.-C., 1996. Production pattern of alkenones in the Mediterranean Sea. Geophys. Res. Lett. 23, 3171-3174.

Trouet, V., Esper, J., Graham, N.E., Baker, A., Scourse, J.D., Frank, D.C., 2009. Persistent Positive North Atlantic Oscillation Mode Dominated the Medieval Climate Anomaly. Science 324, 78-80. 
Fig. 1. Map showing the location of Gol-Ho1B_KSGC-31 site, and spatial field of Mediterranean annual mean SSTs (1955-2012). The insert in the upper right corner shows the monthly SSTs at the core location; the dashed line indicates the annual mean $\left(17^{\circ} \mathrm{C}\right)$ from World Ocean Atlas Database (NOAA/NODC WOA13 ( $1^{\circ}$ grid)). The anticyclonic blocking cell over the northeastern Atlantic and low-pressure system in the central Mediterranean associated to EA is also represented (adapted from Papadopoulos et al., 2012). All sites discussed in the text are shown from West to East: RAPiD-17-5P, South of Iceland (MoffaSanchez et al., 2014); MD99-2275, North of Iceland (Sicre et al., 2011); TTR17-1_384B, 436B, Alboran basin (Nieto-Moreno et al., 2013); MINMC-1,2, Balearic basin (Moreno et al., 2012). Mistral wind is shown by the black arrow.

Fig. 2. KSGC31 gravity core chronology based on ${ }^{210} \mathrm{~Pb}$ (grey dots) and ${ }^{14} \mathrm{C}$ (dark squares) dating and associated error bar at $\pm \underline{1} \sigma(\mathrm{A})$. The insert $\mathrm{B}$ is an enlarged view of the uppermost 0-30 $\mathrm{cm}$ section of the core corresponding to the grey area. The outlier date shown as an empty square was not used in the age model.

Fig. 3. ${ }^{232} \mathrm{Th}(\mathrm{A}),{ }^{210} \mathrm{~Pb}_{\mathrm{xs}}{ }^{\mathrm{Th}}$ (B) and ${ }^{137} \mathrm{Cs}(\mathrm{C})$ profiles determined in the multicore Gol-Ho1B (dark dots) and gravity core KSGC31 (red squares) (see data in Table 2). KSGC31 profiles have been shifted to meet the best correspondence of the plots, yielding a material loss of $15 \pm$ $0.5 \mathrm{~cm}$ in the top of the gravity core. Chronology of the multicore Gol-Ho1B and the top 10 $\mathrm{cm}$ of the gravity core KSGC31 after adjustment based on ${ }^{210} \mathrm{~Pb}$ dating and associated age model uncertainty at $+1 \sigma(\mathrm{D})$.

Fig. 4. SST reconstruction since 1850 AD combining SSTs from the multi-core Gol-Ho1B (light green dashed line and solid dots) and gravity core KSGC-31 (dark green and solid dots). Empty dots indicate the overlapping gravity core SST values with the multicore (A). Spliced Gol-Ho1B_KSGC-31 record built from the two core data (B) (see text for explanations). 
Fig. 5. Alkenone-derived SST reconstruction at the Gol-Ho1B_KSGC-31 site over the instrumental period (A). ${ }^{14} \mathrm{C}$ and ${ }^{210} \mathrm{~Pb}$ error bars on dating are shown for each SST data point. Kaplan instrumental data from 1866 AD to 2012 AD showing annual mean (in purple)(B), FMA months (in blue)(C) (Kaplan et al., 1998). Annual mean values of the East Atlantic (EA) index since 1950 are also shown for comparison with proxy data (D).

Fig. 6. Alkenone-SST time series from the Western Mediterranean Sea and North Atlantic over the last two millennia. (A) core Gol-Ho1B_KSGC-31 (NW Mediterranean Sea) (this study); (B) Cores TTR17-1_384B, 436B from the Alboran basin (Nieto-Moreno et al., 2013); (C) Cores MINMC-1,2 from the Balearic isles (Moreno et al., 2012); (D) core MD99-2275 off North Iceland (Sicre et al., 2011). For (B) and (C) SSTs were recalculated using the calibration of Conte et al. (2006). Dashed lines in (C) highlight the portion of the record that has been extrapolated to present day from the last dated sediment horizon around $1500 \mathrm{AD}$ (see text). Filled areas of the curves indicate negative SST anomaly relative to mean values of each core. A 25-yr binning was applied to all records (dark and red lines) to better visualize anomalies or departures from average conditions. Triangles indicate the AMS ${ }^{14} \mathrm{C}$ control points for all cores. The grey vertical bars broadly highlight the most outstanding cold spells of core Gol-Ho1B_KSGC-31 during the LIA. MCA: Medieval Climate Anomaly; LIA: Little Ice Age.

Fig. 7. A detailed view of the last millennium. (A) Fluctuations of the Great Aletsch and Gorner glaciers in the Swiss Alps (Holzhauser et al., 2005); (B) Retreat/advance of the Langjökull glacier (Iceland) reconstructed from the Hvítárvatn lake varves (Larsen et al., 2013; Ólafsdóttir et al., 2013); (C) Sea ice occurrence traced by the IP25 abundances (Massé et al., 2008) and alkenone-SSTs from core MD99-2275, North Iceland (Sicre et al., 2011); (D) $\mathrm{Mg} / \mathrm{Ca}-\mathrm{SST}$ s obtained from foraminifera calcite of G. inflata in core RAPiD-17-5P, South Iceland (Moffa-Sanchez et al., 2014); (E) Alkenone-SSTs from site Gol-Ho1B_KSGC-31 in the Gulf of Lion (this study); (F) 30-yr Gaussian low-pass filter of winter (DJF) European temperature anomaly (relative to the 1901 - 1995 calibration average) (black line) with two 
standard errors (blue lines) (Luterbacher et al., 2004); (G) The NAO index anomalies calculated in 25-yr averages from the palæo-reconstruction by Ortega et al. (2015) (black line); 7-yr running average of the NAO instrumental (red line) (http://www.esrl.noaa.gov/psd/gcos_wgsp/Timeseries/NAO/nao.long.data). (H) Solar activity anomalies in $\mathrm{W} / \mathrm{m}^{2}$ (Total Solar Irradiance, TSI) calculated in 25-yr averages from the cosmic ray intensity reconstruction (Steinhilber et al., 2012). From (B) to (E) dark and red lines indicate a $25-\mathrm{yr}$ binning. From $(\mathrm{C})$ to $(\mathrm{H})$ filled areas indicate negative anomaly relative to average values, except for (F) whose anomaly was calculated relative to the 1901-1995 calibration interval. Triangles indicate the AMS $-{ }^{14} \mathrm{C}$ control points at $1 \sigma$ uncertainty. The grey vertical bars broadly highlight the major cold spells of the LIA period in the GolHo1B_KSGC-31 record. 
Table 1. Radiocarbon dates and their calibrated ages along the KSGC31 sediment core. Results are reported with a $1 \sigma$ uncertainty.

\begin{tabular}{|c|c|c|c|c|c|c|}
\hline Depth $(\mathrm{cm})$ & Calibration & Material & 14C age & cal year BP & Year AD & $\pm 1 \sigma$ \\
\hline 5.5 & Oxcal 4.2, NH zone 1 post bomb ages curve & Bittium sp. & $420 \pm 30$ & $24^{\mathrm{a}}$ & 1926 & $\overline{60}$ \\
\hline 11.5 & Oxcal $4.2, \mathrm{NH}$ zone 1 post bomb ages curve & Tellina sp. & $430 \pm 30$ & $34^{\mathrm{a}}$ & 1916 & 60 \\
\hline 18.5 & CALIB 7.1, Marine13 curve (Reimer et al., 2013) & Pecten sp. & $720 \pm 40$ & $380^{\mathrm{b}}$ & 1570 & 78 \\
\hline 25.5 & CALIB 7.1, Marine13 curve (Reimer et al., 2013) & Venus sp. & $640 \pm 30$ & 235 & 1716 & 99.5 \\
\hline 41.5 & CALIB 7.1, Marine13 curve (Reimer et al., 2013) & Pecten sp. & $700 \pm 30$ & 339 & 1611 & 79 \\
\hline 52 & CALIB 7.1, Marine13 curve (Reimer et al., 2013) & Indet. bivalve & $960 \pm 30$ & 551 & 1399 & 59 \\
\hline 71 & CALIB 7.1, Marine13 curve (Reimer et al., 2013) & Arca tetragona & $1340+30$ & 852 & 1099 & 80.5 \\
\hline 110.5 & CALIB 7.1, Marine13 curve (Reimer et al., 2013) & Venus sp. & $1465 \pm 30$ & 992 & 958 & 85 \\
\hline 185.5 & CALIB 7.1, Marine13 curve (Reimer et al., 2013) & Nucula sp. & $2235 \pm 40$ & 1806 & 145 & 99.5 \\
\hline 252 & CALIB 7.1, Marine13 curve (Reimer et al., 2013) & juvenile bivalve shells (ind.) & $2940 \pm 30$ & 2676 & -726 & 100.5 \\
\hline
\end{tabular}

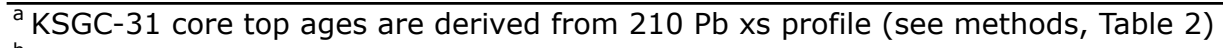

beversal, not used for the interpolation 


\begin{tabular}{|c|c|c|c|c|c|c|c|c|c|c|c|c|}
\hline $\begin{array}{l}\text { Depth } \\
\text { (in cm) }\end{array}$ & & \multicolumn{2}{|c|}{$\begin{array}{l}{ }^{210} \mathrm{~Pb}_{\mathrm{xs}} \\
\mathrm{mBq} \mathrm{g}\end{array}$} & \multicolumn{3}{|c|}{$\begin{array}{c}{ }^{232} \mathrm{Th} \\
\mathrm{mBq} \mathrm{g} \\
\end{array}$} & \multicolumn{3}{|c|}{$\begin{array}{c}{ }^{137} \mathrm{Cs}^{-1} \\
\mathrm{mBq} \mathrm{g}^{-1}\end{array}$} & \multicolumn{3}{|c|}{$\begin{array}{l}\text { Age in years AD } \\
\text { Mean }\end{array}$} \\
\hline Multi-core & GOL-HO- & 1-1- & & & & & & & & & & \\
\hline 0.5 & 72 & \pm & 9 & 22 & \pm & 1 & 3 & \pm & 1 & 2012 & \pm & 0 \\
\hline 1.5 & & & & & & & & & & 2010 & \pm & 0 \\
\hline 2.5 & 74 & \pm & 9 & 22 & \pm & 1 & 4 & \pm & 1 & 2008 & \pm & 1 \\
\hline 3.5 & & & & & & & & & & 2006 & \pm & 1 \\
\hline 4.5 & 73 & \pm & 8 & 21 & \pm & 1 & 4 & \pm & 1 & 2003 & \pm & 1 \\
\hline 5.5 & 64 & \pm & 8 & 22 & \pm & 1 & 4 & \pm & 1 & 2001 & \pm & 1 \\
\hline 6.5 & 58 & \pm & 5 & 21 & \pm & 1 & 4 & \pm & 0 & 1998 & \pm & 2 \\
\hline 7.5 & & & & & & & & & & 1996 & \pm & 2 \\
\hline 8.5 & 52 & \pm & 5 & 23 & \pm & 1 & 4 & \pm & 0 & 1993 & \pm & 2 \\
\hline 9.5 & & & & & & & & & & 1990 & \pm & 2 \\
\hline 10.5 & 45 & \pm & 7 & 25 & \pm & 1 & 4 & \pm & 1 & 1987 & \pm & 3 \\
\hline 11.5 & & & & & & & & & & 1985 & \pm & 3 \\
\hline 12.5 & 48 & \pm & 5 & 23 & \pm & 1 & 4 & \pm & 0 & 1982 & \pm & 3 \\
\hline 13.5 & & & & & & & & & & 1979 & \pm & 4 \\
\hline 14.5 & 27 & \pm & 4 & 26 & \pm & 1 & 4 & \pm & 0 & 1976 & \pm & 4 \\
\hline 15.5 & 30 & \pm & 5 & 25 & \pm & 1 & 3 & \pm & 0 & 1973 & \pm & 4 \\
\hline 16.5 & 32 & \pm & 4 & 25 & \pm & 1 & 3 & \pm & 0 & 1970 & \pm & 5 \\
\hline 17.5 & & & & & & & & & & 1967 & \pm & 5 \\
\hline 18.5 & 21 & \pm & 4 & 28 & \pm & 1 & 2 & \pm & 0 & 1963 & \pm & 5 \\
\hline
\end{tabular}

Gravity core KS-GC-31

\begin{tabular}{|c|c|c|c|c|c|c|c|c|c|c|c|c|}
\hline 0.5 & 28 & \pm & 5 & 26 & \pm & 1 & 3 & \pm & 0 & 1971 & \pm & 1 \\
\hline 1.5 & & & & & & & & & & 1965 & \pm & 2 \\
\hline 2.5 & 17 & \pm & 6 & 28 & \pm & 1 & 2 & \pm & 1 & 1959 & \pm & 3 \\
\hline 3.5 & & & & & & & & & & 1953 & \pm & 5 \\
\hline 4.5 & 21 & \pm & 6 & 30 & \pm & 1 & 2 & \pm & 1 & 1946 & \pm & 6 \\
\hline 5.5 & 20 & \pm & 6 & 29 & \pm & 1 & 1 & \pm & 1 & 1940 & \pm & 8 \\
\hline 6.5 & 14 & \pm & 6 & 31 & \pm & 1 & 1 & \pm & 1 & 1934 & \pm & 10 \\
\hline 7.5 & 8 & \pm & 5 & 29 & \pm & 1 & 0 & \pm & 1 & 1928 & \pm & 11 \\
\hline 8.5 & 5 & \pm & 5 & 29 & \pm & 1 & 0 & \pm & 0 & 1922 & \pm & 13 \\
\hline
\end{tabular}




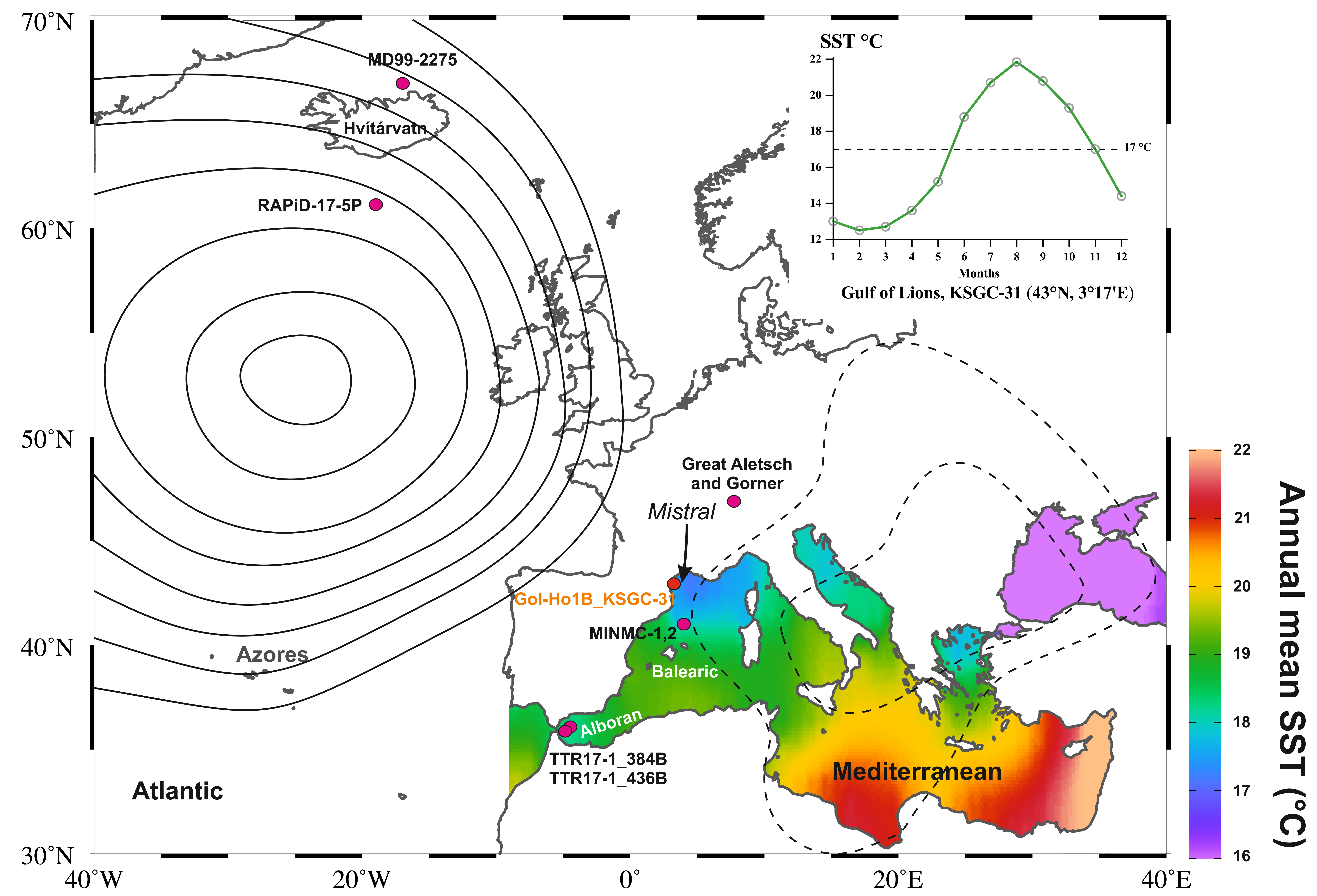

Figure 1 
Age (years AD)

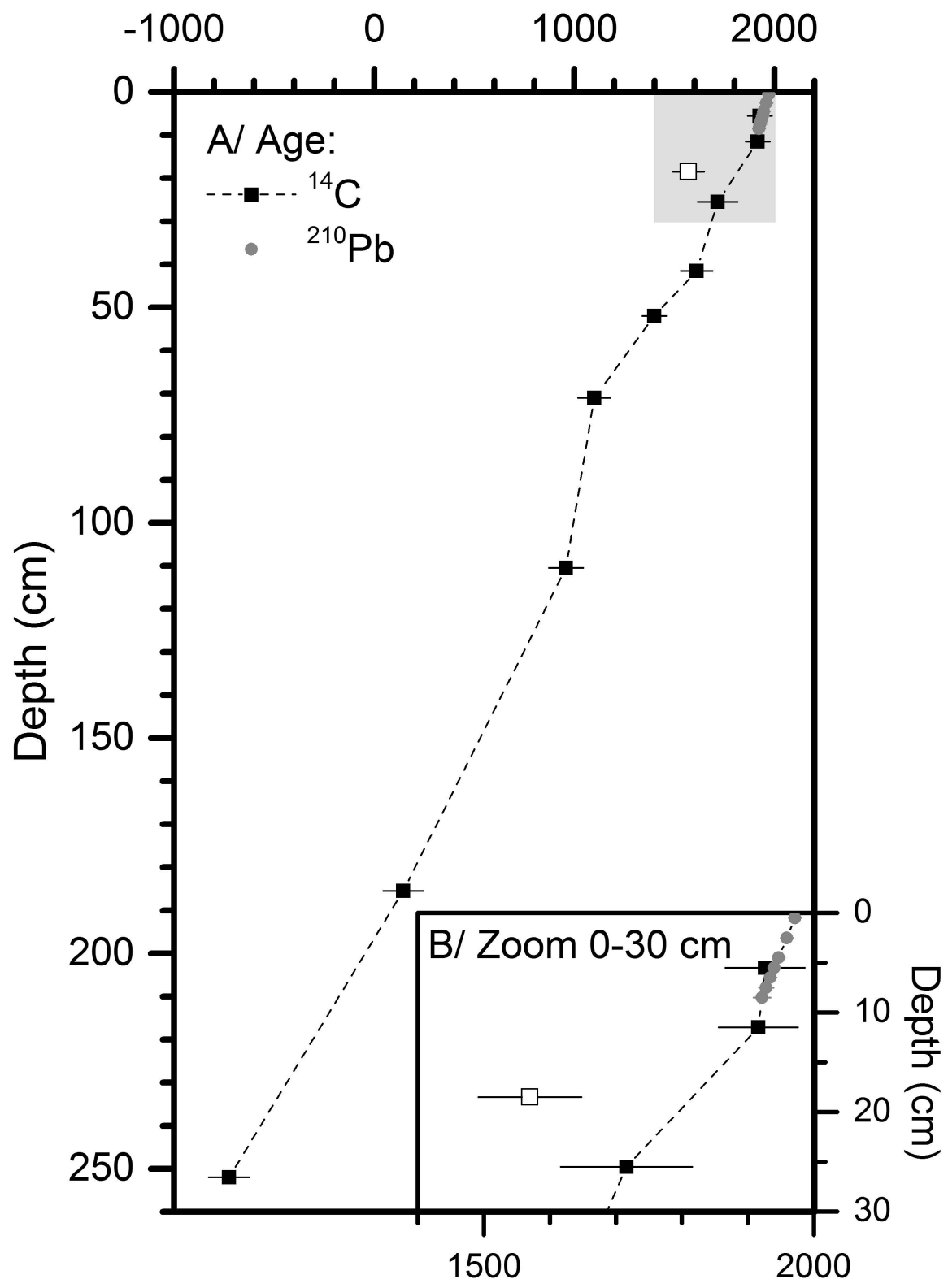




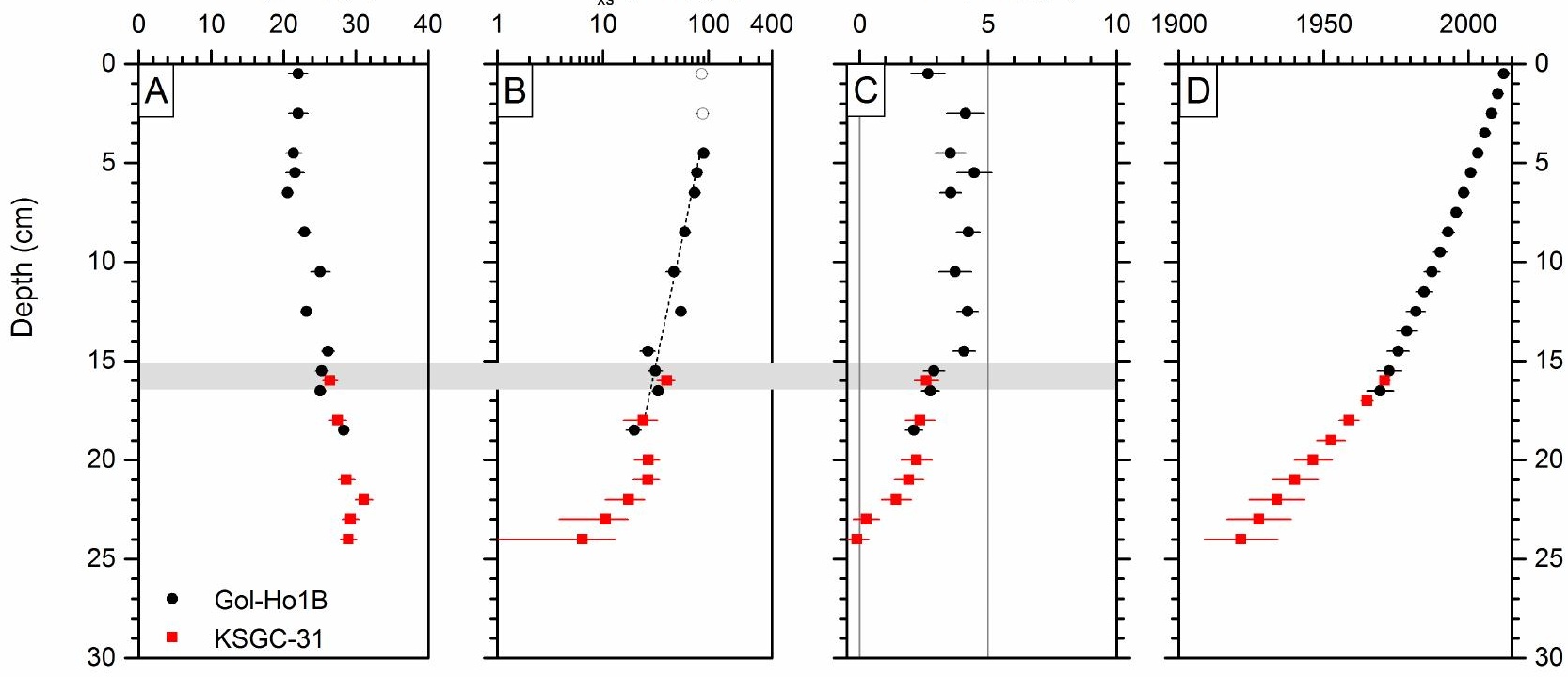




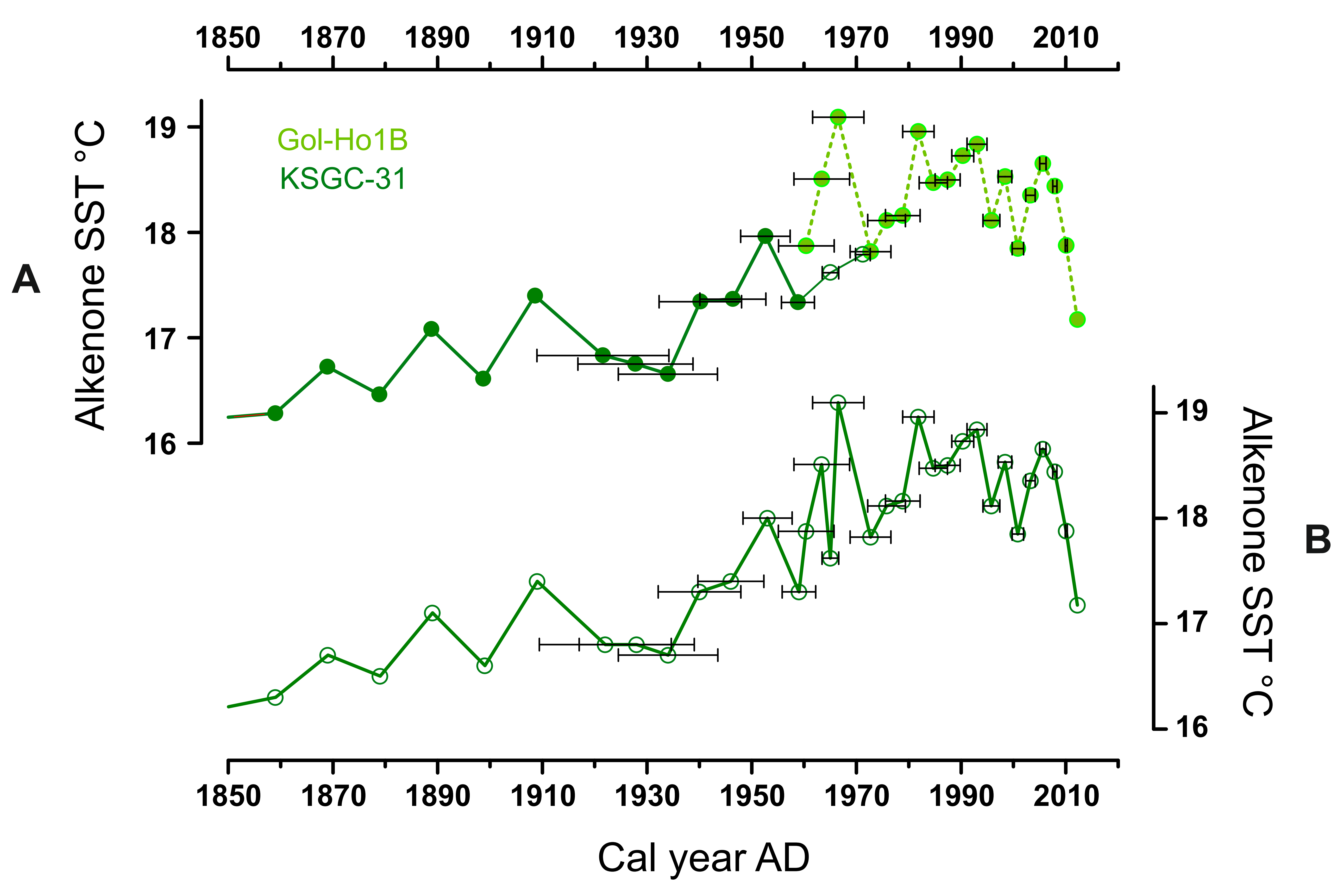

Figure 4 


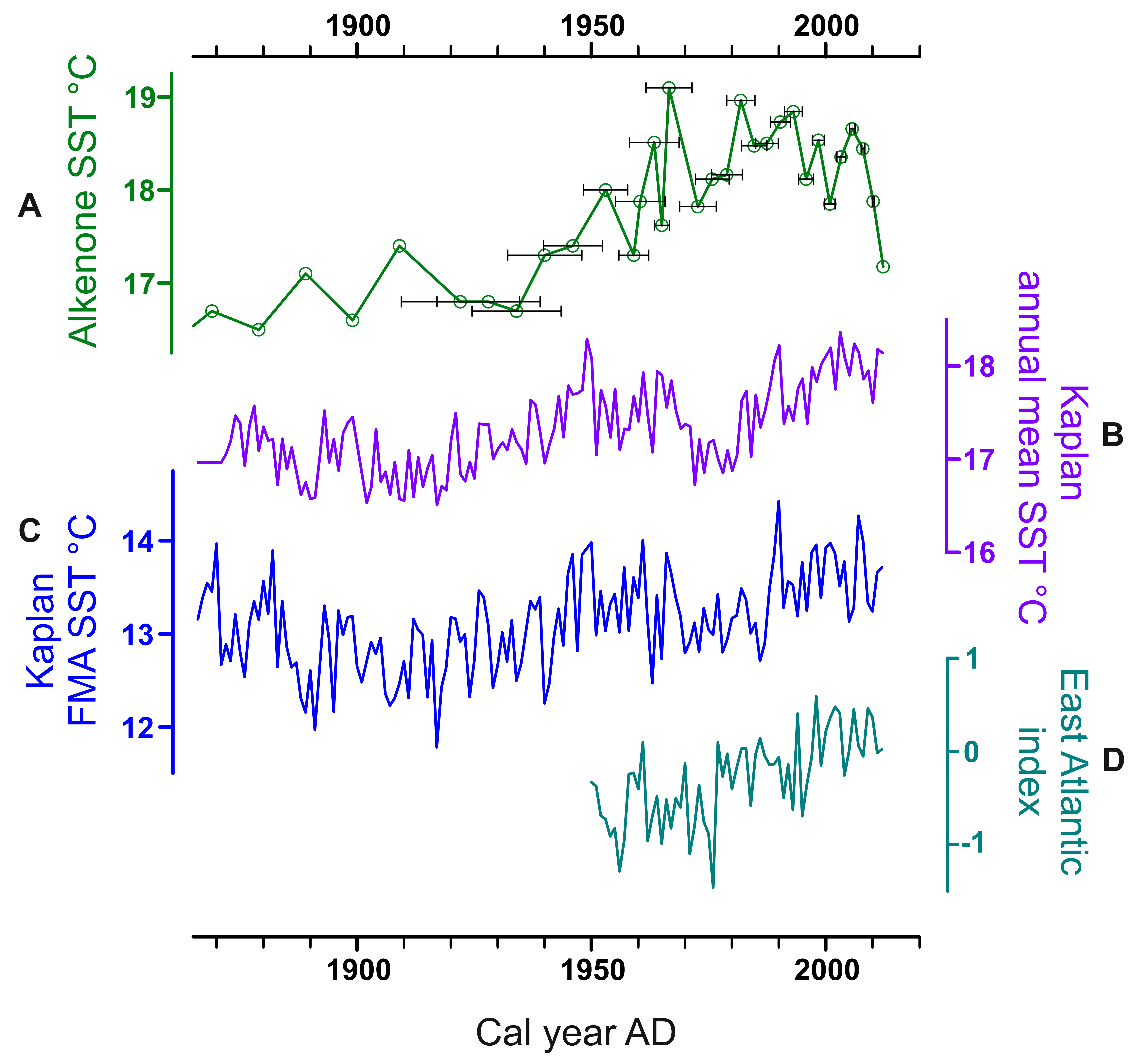

Figure 5 
cal year AD
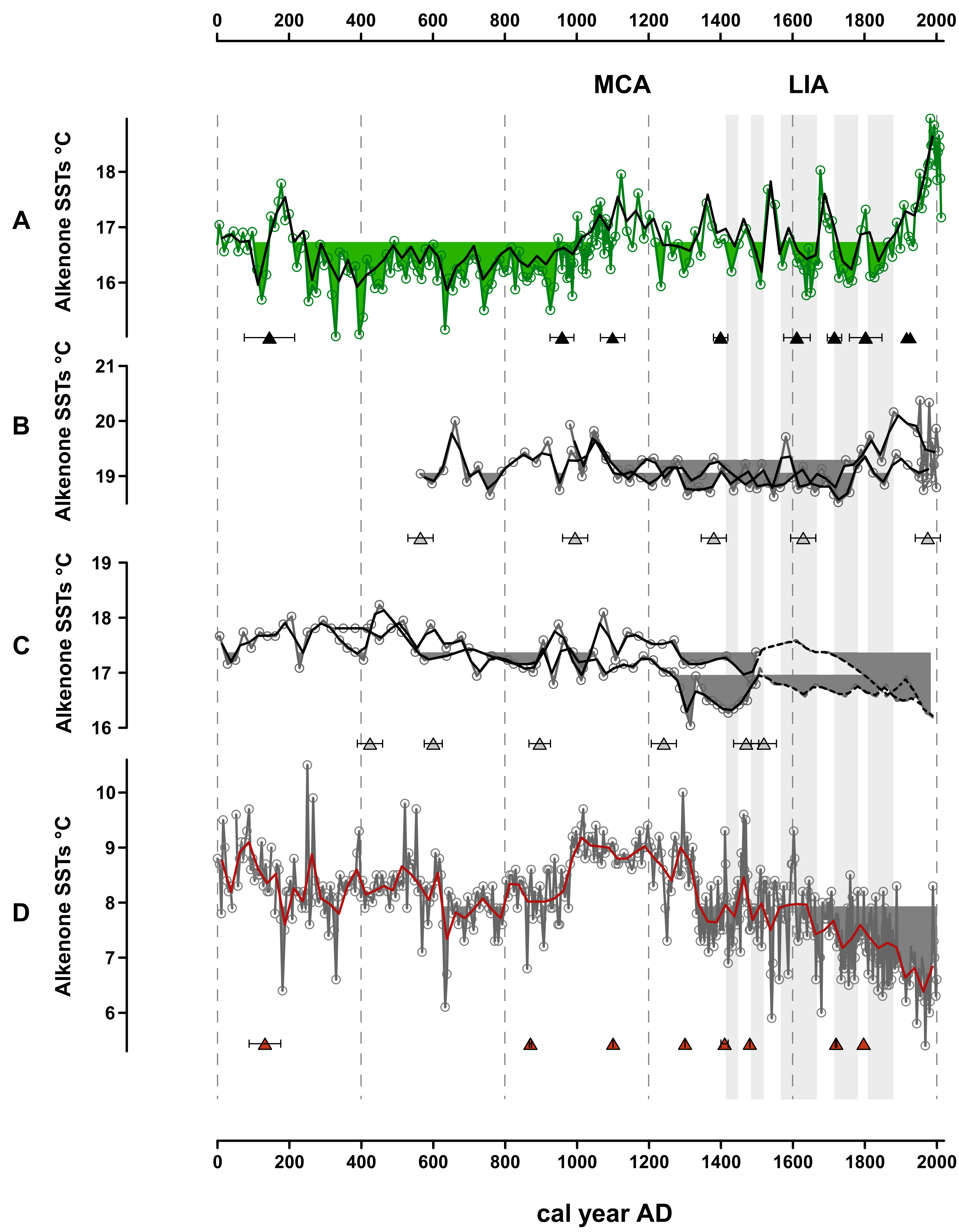

Gulf of Lions $\left(43^{\circ} \mathrm{N}, 3^{\circ} \mathrm{E}\right)$ Gol-Ho1B_KSGC-31 (this study)

Alboran basin $\left(36^{\circ} \mathrm{N}, 5^{\circ} \mathrm{W}\right)$ TTR17-1_384B, 436B

Balearic isles $\left(41^{\circ} \mathrm{N}, 4^{\circ} \mathrm{E}\right)$ MINMC-1,2

\section{$\mathrm{N}$ Iceland $\left(67^{\circ} \mathrm{N}, 17^{\circ} \mathrm{W}\right)$} MD99-2275

Figure 6 
cal year AD

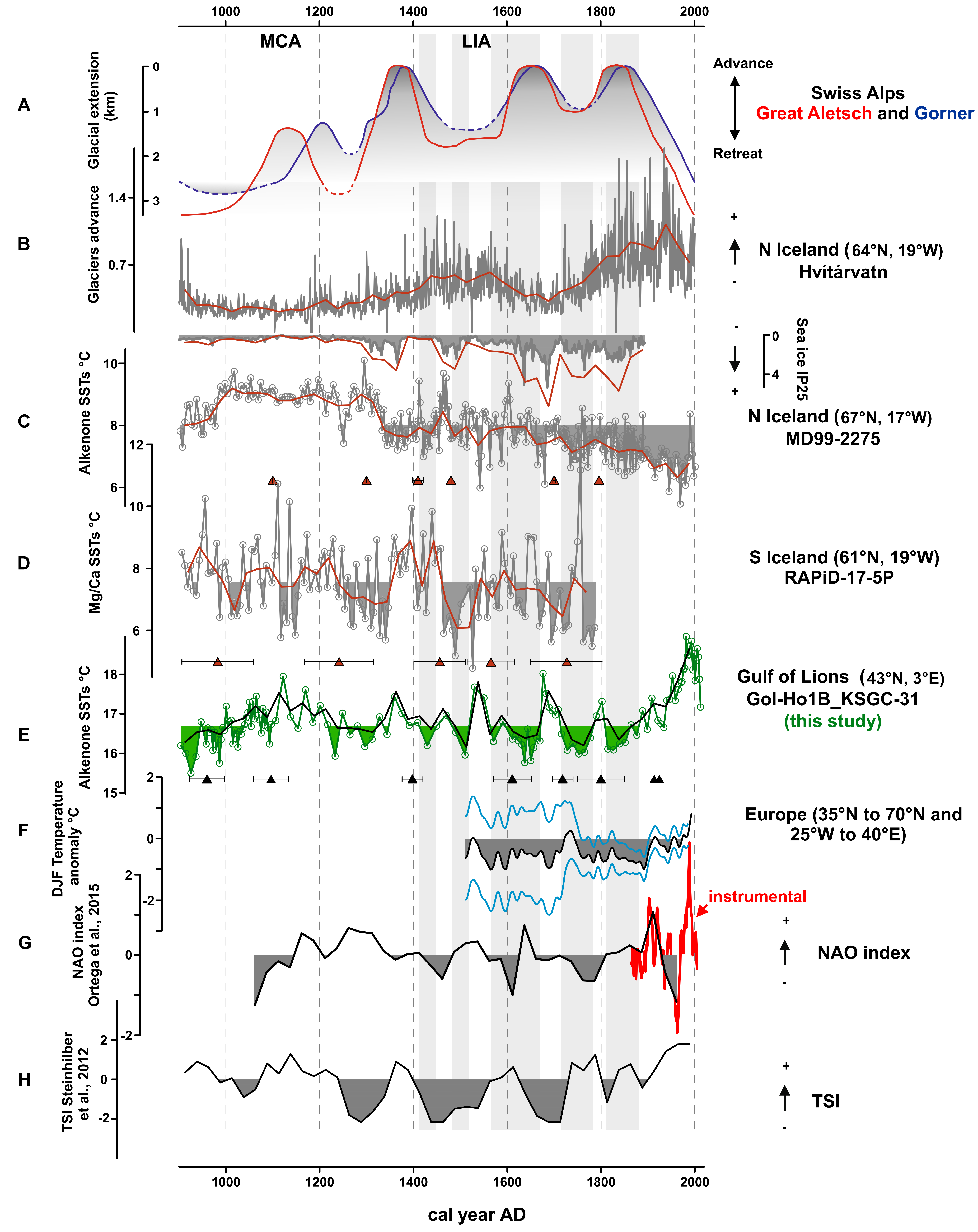

Figure 7 